\title{
RESTORATION OF THE BISHOP DANILO'S MAUSOLEUM AT EAGLE'S ROCK, CETINJE (MONTENEGRO)
}

\author{
Svetislav G. Popović, Dragutin Đuričić, Svetlana K. Perović
}

Professional paper

The case study refers to the restoration of the Bishop Danilo's mausoleum at Eagle's Rock, in Cetinje Royal Capital of Montenegro. This is one of the most significant unmovable cultural heritage monuments in Cetinje's historic center. Presentation of the project for the restoration of the mausoleum and the process of construction works indicated the specificity and sensitivity of the restoration and conservation of cultural monuments that carry significant messages from the history of the people and are a part of collective memory. During the last three decades, the mausoleum was repaired twice. The first structural sanation was done in 1985, eliminating consequences of the earthquake of 1979, and the other one was done on the initiation of the Republic Institute for Protection of Cultural Monuments in Cetinje, following an investigation of the existing state of the mausoleum's structure, which was conducted in 2004. This paper presents the character of defects that occurred over time and were found during the investigation of the structure of the object, the causes of defect occurrence, conservation requirements for the restoration, choice of the most rational solution in 2007, method for construction works on the object, as well as the review of the object after the completion of the restoration in 2011. Research results point out the complexity of the restoration of objects that have special cultural value, regardless of the dimensions and complexity of the architectural structure itself.

Keywords: complexity; cultural monument; restoration; structural damage; specificity

Restauracija mauzoleja vladike Danila na Orlovom kršu, Cetinje (Crna Gora)

Studija slučaja se odnosi na restauraciju mauzoleja vladike Danila na Orlovom kršu, u crnogorskoj prijestonici Cetinje. Ovo je jedan od najznačajnijih spomenika nepokretne kulturne baštine u istorijskoj jezgri Cetinja. Kroz prikaz projekta restauracije mauzoleja i postupak izvođenja radova ukazano je na specifičnost i osjetljivost restauracije i konzervacije spomenika kulture koji nose značajne poruke iz povijesti naroda i dio su kolektivne memorije. U posljednje tri decenije mauzolej je dva puta restauriran. Prva strukturna sanacija je izvršena 1985. gdje su otklonjene posljedice od potresa iz 1979., a druga na prijedlog Republičkog zavoda za zaštitu spomenika kulture na Cetinju nakon istraživanja postojećeg stanja konstrukcije mauzoleja koja su provedena 2004. U radu je prikazan karakter oštećenja koja su zatečena prilikom istraživanja konstrukcije objekta kroz vrijeme, uzroci njihovog pojavljivanja, zatim konzervatorski uvjeti za restauraciju, izbor najracionalnijeg rješenja 2007., postupak izvođenja radova na objektu kao i prikaz objekta nakon završetka restauracije 2011. Rezultati istraživanja ukazali su na kompleksnost u restauraciji objekata posebnih kulturnih vrijednosti, bez obzira na dimenzije i složenost same arhitektonske strukture.

Ključne riječi: kompleksnost; restauracija; specifičnost; spomenik kulture; strukturna oštećenja

\section{Introduction (Research Aims)}

According to the Council of Europe, the architectural heritage constitutes an irreplaceable expression of the richness and diversity of Europe's cultural heritage, bears inestimable witness to our past [1]. Sustainable conservation and restoration of cultural built heritage of "outstanding universal value" [2], require a high level of professionalism, collective engagement, and systemic approach [3].

The main objective of the study was the restoration of Bishop Danilo's Mausoleum at Eagle's Rock, which should contribute to the conservation of architectural cultural heritage. Severe damages to the object, that were created over time, required a detailed analysis of different parameters, from the urban context, historical and socioeconomic facts, factors that have shaped the monument, identification of the character of changes on the construction, conservation requirements etc. Primary goals of a more complex investigation concerned the definition of a proposal for concrete intervention on the object, development of an optimal solution for the restoration of the object and its implementation, with maximum preservation of the visual identity of the mausoleum and compliance with the conditions for a sustainable cultural heritage.

\section{History of the mausoleum}

Eagle's Rock (800 m.a.s.l.) is a hill in the southwestern part of the Cetinje field (671 m.a.s.l.) (Fig.1a), and is deemed to be named after the fact that once there were flocks of eagles flying above it, that have since disappeared from the area [4]. In 1853, Knyaz Danilo decided to build a monument to his ancestor at Eagle's Rock [5]. Through the architectural call for proposals a solution was chosen, and it came from Knyaz's daughter Jelena, who later became an Italian queen. Knyaz of Montenegro Nikola Petrovic, in a letter to the Italian Queen Margarita, wrote that the chosen solution was modest, not expensive and artistically conceived from the aspects of location and architecture [6]. The project was developed by a French architect Fruse and sculptor Paul Moreau Vauthier. So in 1896, for the $200^{\text {th }}$ anniversary of "the happy reign of their holly home" [7] of the Petrovic dynasty, the mausoleum for the founder of the dynasty Danilo Petrovic Njegos was built at Eagle's Rock in Cetinje. The complex of the mausoleum (Fig. 1b and 1c) is made up of a plateau with the monument, a park and a rainwater tank (well). The monument was incorporated into the natural context and with its authentic values represents a recognizable symbol of Cetinje.

The monument as a symbol represents a kind of collective identification that sociologist Rudi Supek expresses through the definition: Symbols are the most 
appropriate means in establishing continuity in time, marking stages in tradition, events in history, distant and current one, in other words, to warn to the rootedness of man in his own cultural and national history [8]. The mausoleum at Eagle's Rock offers a great view of the town and Cetinje field, and the access road is a favourite promenade for the citizens. The mausoleum is legally protected since 1957, and in terms of cultural value categories it is classified as an unmovable cultural heritage of II category.

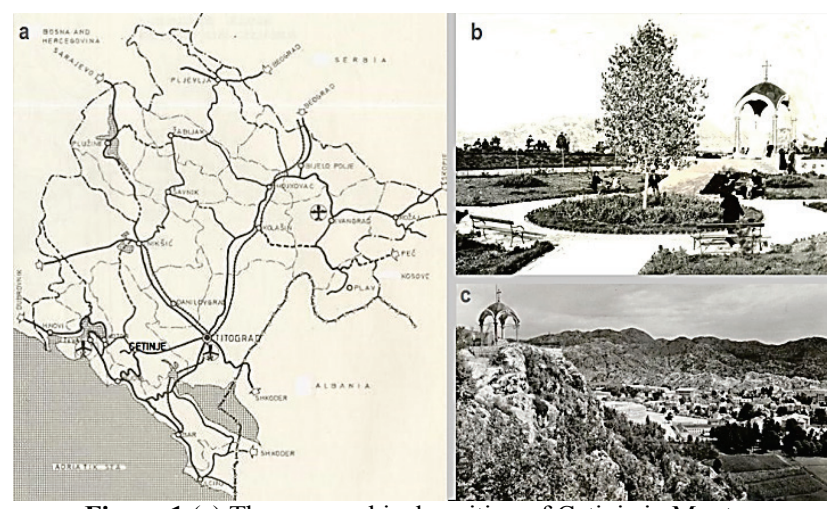

Figure 1 (a) The geographical position of Cetinje in Montenegro; (b) Mausoleum complex at Eagle's Rock; (c)Panorama of Cetinje from Eagle's Rock in 1937

\subsection{Architectural and structural assembly of the Mausoleum}

From a standpoint of general attributes of the mausoleum structure, the object is derived from elements of ashlar and moulded stone. Pillars consist of a single part with a capital with two arches. The arches are made from three ashlar and ornamented stones. The cupola is made of reinforced concrete, with a thickness of about 20 $\mathrm{cm}$.

The mausoleum was built on a plateau that is $11 \times 11$ $\mathrm{m}$ in size. It consists of a tomb and a baldachin which rises above it. On the west side of the tomb is stone plaque with a cross. On the top plate of the tomb there is a relief in the stone with symbols of secular and spiritual authority of the bishop. The metropolitan scepter from the side is framed with laurel and olive branches. Across the middle there are two crossed scimitars. Incorporated on the eastern side is a bronze circular medallion (authored by the sculptor Paul Moreau Vauthier) with the bishop's profile. Sides of the sarcophagus are decorated with stylized flowers and a cross in circular frames, cut in stone in relief. Stone plaque that bears the cross has the inscription: "Metropolitan Danilo, sovereign of Montenegro. Born in the year 1677. Came to power in the year 1696. Passed on in the year 1735". Above the tomb, on four Doric pillars there is a baldachin (vault) representing a starry sky. The vault rests on pillars via its arches. The arches have decorative wreaths in the shape of astrakhan, on the basis of which there is per one cornerstone with relief crests on the front side (state, family and bishop). On the lower side of these stones there are decorative stylized flowers with different numbers of leaves. The sky is in the shape of a spherical section, starry and blue coloured [9].

\section{Experimental section 3.1 Introduction}

Sustainable conservation and restoration of cultural heritage require a high level of professionalism, collective engagement, and systemic approach [3]. Restoration of cultural heritage that contributes to the development of cultural continuity requires an interdisciplinary research engagement [10]. Cultural monuments, regardless of their complexity, are very demanding in the process of restoration. Restoration is quite rare and complex and financially demanding, it takes a multidimensional treatment of the problem with respect to the historical context but also with the incorporation of modern models of restoration for sustainable development. The presented case study suggests caution in the selection of methodological procedures in restoration of prominent cultural monuments.

\subsection{Overview of the mausoleum sanation in 1985}

Due to the earthquakes in 1979 and 1980, the structure of the mausoleum was significantly damaged, especially at the joints of decorative stone arches of the cupola. The investigation in 1984 ascertained damages to the object as follows: penetration of moisture through the damaged roof cladding, formation of mould and mildew, dissolution and leaking of plaster inside the body of the cupola and the lower layer of the cupola. Disruption in the corpus of the stone pillars, perceived caverns resulting from weather conditions (rain, wind, frost, etc.) along the pillars. Visible irregular shapes of caverns on the pillars spread out in width and depth like a thread network which in some parts reaches a width and depth of $5 \mathrm{~mm}$. Observed damages on the object caused by the human factor - firearms (piercing through the copper cover of the cupola, tearing off parts of decorative stone arches of the cupola and parts of the stone pillars). In the fundament zone there were no damages, given that the bottom is a rock.
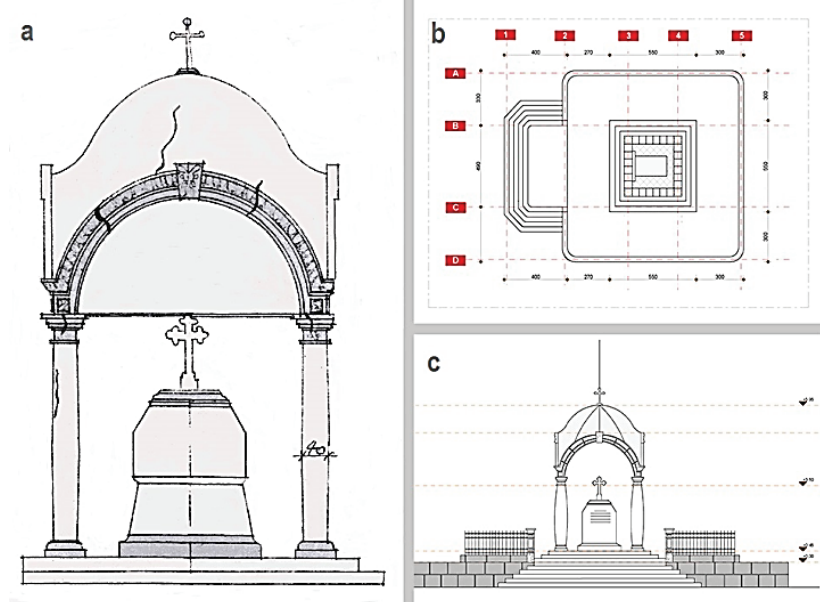

Figure 2 (a) Impairments recorded in 1984; (b) The basis of the mausoleum; (c) The appearance of the mausoleum from the west side

The preparation of the restoration project (Fig. 2) in 1985, had scheduled reinforcement of the structure, using the substrate of the existing state, assessed seismic parameters and the assessment of the structure being 
founded on a rock. The corresponding calculation that was performed for the restoration of the object was based on the gravitational load where it was noted that the object as a system meets the requirements of stability and seismic loads by the method of equivalent static load.

The restoration proposal included the injection of connectors of all stone elements with epoxy resins and bonding of the tie rods to the bodies of the capital with clamps. The drill holes in the connector zone are of a max. $8 \mathrm{~mm}$ in diameter, made at a distance of 30 to $40 \mathrm{~cm}$, depending on the size of the stone blocks. The drill holes were dusted off with compressed air. In order to achieve the required connection of the structure elements, the needed pressure was $70 \mathrm{MPa}$ and tensioning of $30 \mathrm{MPa}$ [11].

\subsection{The project of mausoleum restoration in 2007}

The project for the restoration of monuments [12] was prepared on the basis of conducted investigation of the existing condition of the structure, by the Republic Institute for Protection of Cultural Monuments in Cetinje, planners and provided conservation requirements.

\subsubsection{Investigation of the existing state of the structure}

Conducted investigation of the existing state in 2007 pointed out the reduction in capacity of the structure that was noted on the spot, with the results indicating the urgency for restoration of the supporting structure. The following was noted through the examination:

- Vault of the cupola is threatened and in danger of collapsing, its stability is directly affected by the most of harmful atmospheric impacts (polluted air, erosion, frost and ice, lightning discharge). The cupola is covered with copper sheeting which corrodes and the rinsing of the corroded layers further devastates vaults, capitals, pillars, stands of the pillars, as well as the plateau of the entire complex.

- The arches of the cupola are in very poor condition. All of the stone elements are in a poor connection with each other, having virtually no binder between them. The lack of high-quality connectors has caused a disruption in the geometry of the arch, and therefore a shift (lowering) of the individual parts of the arch, which has then caused direct contact between the stone elements, and the occurrence of sporadic fragmentation. (Fig. 3b and 3c).

- Vertical Doric pillars (Fig. 3a) are in danger of collapsing. At the bodies there are visible vertical cracks with damages present on the pedestal and the capital. The pillar located in the south-west has cracked to such an extent that there is risk of fracture. Other pillars are structurally somewhat better. In the upper levels of all four pillars there are visible, very dangerous cracks. Existing cracks allow atmospheric water to penetrate into the interior of the pillars which is a further destructive activity that is threatening the rest of the healthy part of the material. The part where pillars and arches connect has an iron sag rod that connects all four pillars, at the support of the cupola, in all four points of the column capitals and thus reinforces the entire structure. Tie rods are in good condition, in spite of the rust.

\subsubsection{General condition of the mausoleum before restoration}

The mausoleum was in pretty bad condition. Damages were visible in all segments, starting from the access flight of steps, plinth, stone floor with a considerable number of broken plates, pillars, baldachin and copper sheet with which it is covered, metal cross on top, utterly ruined and damaged "starry sky" (Fig. 3e) and two partially damaged pillars out of four in total. Stone plastic was in good condition and did not require major interventions. Established damages appeared in the zone of the arch support on three capitals in the form of cracks running up to half of the pillar diameter. Ties were placed at the outer perimeter of the capital (Fig. 3d).

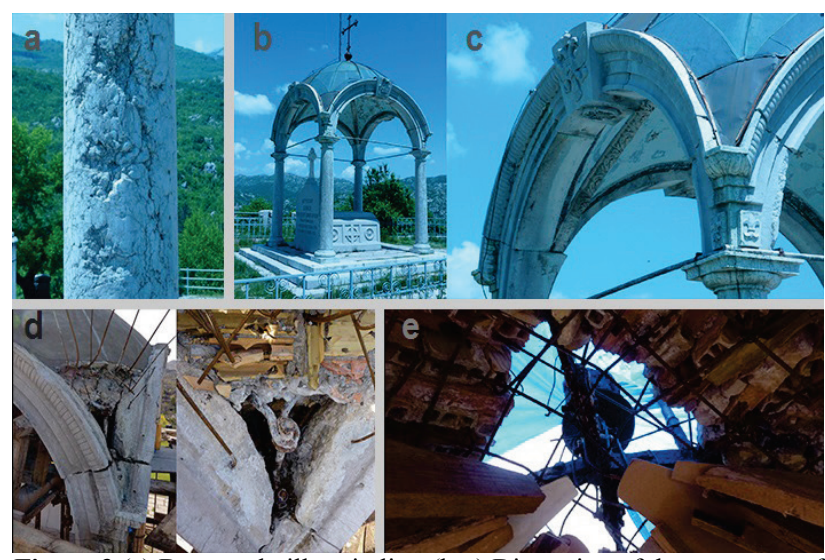

Figure 3 (a) Damaged pillar vitality; (b-c) Disruption of the geometry of the vault; (d) Damage of the calotte support; (e) Damage of the vault.

\subsubsection{Conservation requirements}

The conservation and restoration works on the Bishop's Danilo mausoleum at Eagle's rock in Cetinje demand the compliance with the following conservation requirements:

- Preservation of existing architectural artistry and the existing ambient of the Eagle's Rock;

- Preservation of existing original matter of the tomb, baldachin and fence wall along the entire platform;

- Performing a static sanation and consolidation of endangered architectural parts - support pillars;

- Particular attention should be focused on the analysis of the level of damage to the support pillars, for the sake of capacity of the vault structure;

- To examine the level of degradation of the pillars structure and to calculate the Henry's constant of the capillary moisture impact from the base up to the top of the pillar. Based on the resulting calculations, the outside of the pillars are to be covered with adequate protection which, by its quality, structure and colour relation, will not violate the appearance of the pillars. In case the results of the analysis show the necessity for it, concreting under the pillars is to be done, based on geo-mechanical examination of the ground;

- To consolidate the four supporting pillars of the baldachin, that are made up of segments, to return them back to the geometric plane, reinforce their 
connections and to ensure their geometry at the level of the connection with ties of high quality new material. In this way, it will be possible to rehabilitate the interior of the baldachin with ribs;

- Damage of the groined vault with reinforcing ribs and a central rosette is to be repaired using modern materials that are resistant to moisture, and thus allow the setting up of a corresponding coloured layer in spherical triangles with light-blue tones and gilded decorative plastic (rosettes, palmettes, stars). The aesthetic presentation of the vault and vault decoration must be covered by a specific elaborate.

\section{Results and discussion}

Within the project of the object's restoration three alternatives for providing stability have been proposed: to replace the stone pillars, to hem them with steel strips and to drill with injecting. There have not been similar procedures in replacing stone pillars in Montenegro. Encouraged by the example and the knowledge from Replacement of stone columns at the ground floor of the Veliki Tabor castle [13], a proposed type of solution was swapping two of the four pillars with new ones. In favour of replacing the pillars was the notion of emerged caverns on the pillars, cracks that went in favour of the suspicion that their state really requires a change. This version has proved to be economically irrational. A version that required hemming the pillars with steel rings is often in practice, but it was not acceptable by the Republic Institute for Protection of Cultural Monuments in Cetinje, because it would disturb the authenticity of the object, according to the strict conservation requirements. The third version, pillar drilling with injecting, was selected as an alternative solution to the replacement of the pillars, as it was proven that it ensured object's stability. The stability of the object is confirmed by checking the samples for the state of the pillar core.

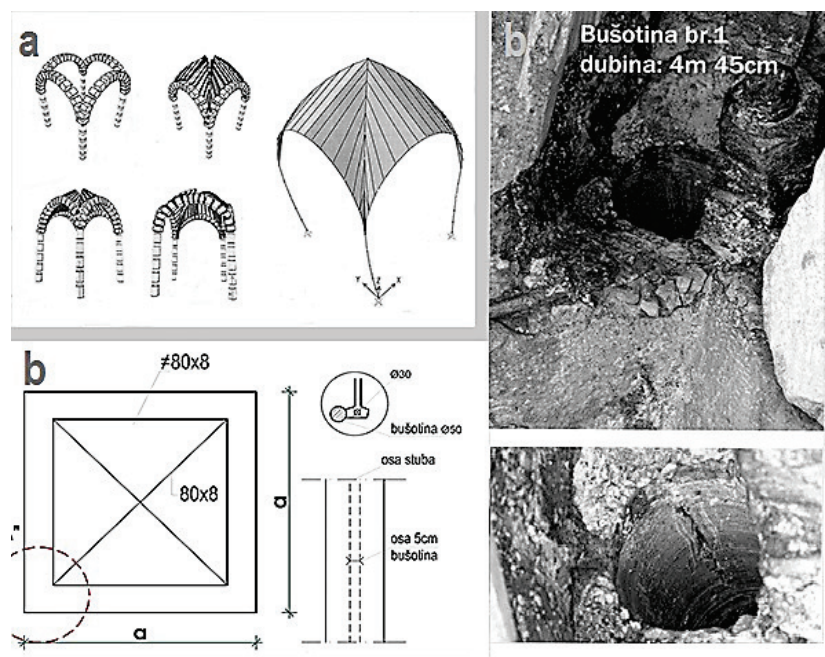

Figure 4 (a) The calculation model; (b) Drilling in the pillar at the point of arcade connection.

Based on the analysis of existing geometry, size and distribution of the load on the calculation model (Fig. 4a), identification of the structure was performed concluding that the foundation is of reinforced concrete, pillars are granite monolith, cupola - vault has a filling of brick blocks set up in a steel frame. This kind of a constructive system of pillars and cupola provides auto-stability of the vault that is leaning on and is pivotally linked to the pillars.

The vault is uncovered, i.e. the copper sheet was removed, the cement screed was cleaned up to the filling brick blocks, lower surface of the cupola has been removed, also up to the filling. The core of the vault (steel construction with brick block filling) was reinforced from upper and lower surface by a network of $\varnothing 8 / 15$ diameter in both directions and it was connected with pins of $\varnothing 8 / 20$. Along the contour in the arch zone, a ring of $3 \varnothing 12$ was formed. Concreting of the lower surface of the vault gave a reinforced concrete shell with a thickness of 3.00 $\mathrm{cm}$, and concreting of the upper surface gave a reinforced concrete shell with a thickness of $5.00 \mathrm{~cm}$. These two reinforced concrete shells connected with pins, together with the filling and the existing steel structure, have formed an auto-stable vault.

Drilling in the pillar was conducted at the spot of connection of the arcades, in the direction of vertical suspension. Pillars were drilled along the axis, along the entire height. Changes on the pillar matter were reviewed on the extracted samples, i.e. whether and how far did the process of corrosion attack the pillars. It was shown that the core is conserved. Armature of $\mathrm{R} \varnothing 19$ was placed in the holing, suffused with SIKODUR 45, a three component epoxside mortar (Fig. 4b). The procedure included the drilling of all four pillars vertically, their strengthening with reinforced iron and a filling on the basis of epoxy resin.

Sikodur mortar penetrates, and fills all pores and bubbles in the holing zone (if there was any), forming a uniform mass of the pillars. Cross-sections of the pillars were computationally tested by about $20 \%$ smaller crosssectional surface. About 15 litres of Sikadur was needed to fill out individual holing - 42 .

In an auto-stable baldachin, ties could serve only as decoration, and for this reason they were removed as they had no function which would influence stability.

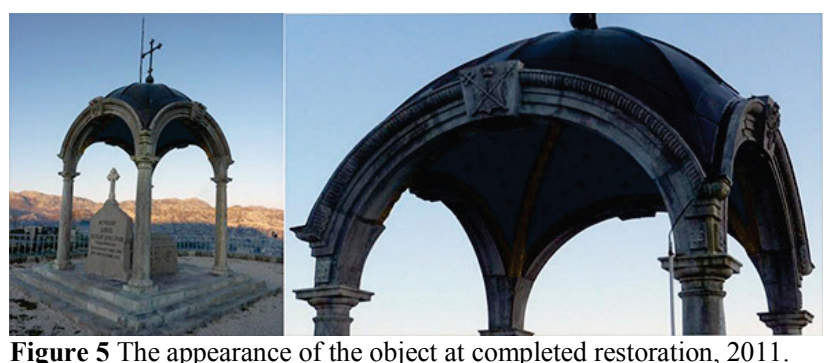

The restoration implied preserving the authenticity of the monument, while ensuring its stability. The calculation was implemented on a spatial model, gravitational load and inertial force of the earthquake of IX degrees MCS, and has proven its stability. Restoration of the object was realized according to the project, which has provided the preservation of authentic values of architectural and cultural heritage (Fig. 5). 


\section{Conclusion}

From the grand opening of the mausoleum of Bishop Danilo Petrovic in 1897, at the time of the celebration of 200 years of the reign of the first Petrovic in Montenegro, the mausoleum has resisted time until the earthquake that struck Montenegro in 1979, when damages were recorded. The structure that goes back for more than 150 years could not resist the seismic shifts so damages occurred in many places. Project feasibility study in 1985 made a stable structure system with retaining, according to the original project, the ties which were, in a frame form, holding the system.

Nevertheless, it turned out eventually that there were irregularities in the construction, primarily due to the use of poor quality materials, so that in the period of the last 20 years there has been a disorder in object's geometry. The entire structure had to be put in the status quo ante, starting with the calotte and up to the pillars that were severely damaged.

Project planners faced certain dilemmas as far as which system to choose. Considering positive experiences from other places, it was contemplated whether to carry out a replacement of the pillars or to do another version which referred to the setting up of steel rings around the pillars that would prevent crumbling. However, due to conservation requirements, preservation of the object's visual identity, complexity of the replacement works, as well as financial conditions, the third version was selected and it included placing reinforcement with suffusing the mass at the centre of the pillars' core.

This procedure gave a new experience for restoration of objects that are under a special protection regime. The dilemmas that were present during the restoration were removed through practical problem solving on the spot, with subsequent numerical checks.

\section{References}

[1] Council of Europe. Convention for the Protection of the Architectural Heritage of Europe. Granada, Spain. 1985. http://www.coe.int/en/web/conventions/full-list//conventions/rms/090000168007a087

[2] UNESCO. Convention Concerning the Protection of the World Cultural and Natural Heritage. Paris, France, 1972. http://www.refworld.org/docid/4042287a4.html

[3] Perhavec, D. D.; Rebolj, D.; Suman, N. Systematic approach for sustainable conservation. // J. Cult. Herit. 16, 1(2015) , pp. 81-87. https://doi.org/10.1016/j.culher.2014.01.004

[4] Popović, S. Danilovgrad-architectonics and symbolism of space. Zadužbina Andrejević, Beograd, 2011.

[5] Pavićević, B. Istorija Crne Gore 4. NP Pobjeda, Podgorica, 2004.

[6] Dragićević, R. Nekoliko potpuno ili djelimično nestalih spomenika kulture. Starine Crne Gore VI. Cetinje, 1978.

[7] Rotković, R. Crna Gora i Dušanovo carstvo.Grafos, Cetinje, 1997.

[8] Supek, R. Grad po mjeri čovjeka. ITRO Naprijed, Zagreb, 1987.

[9] Milić, B. Urbano nasleđe Crne Gore sa posebnim osvrtom na razvoj Cetinja.Orion art, Beograd, 2013.

[10] Perhavec, D. D.; Šuman, N. Historical Building Renovation as a Construction Project. // Journal of Civil Engineering and Architecture. 7, 6(2013), pp. 712-722.
[11] Popović, S.; Stanković, V. Mauzolej vladike Danila ibistijerna na Orlovom kršu - Cetinje. Glavni građevinski projekat. RZUP, Podgorica, 1985.

[12] Popović, S.; Đuričić, D. Mauzolej vladike Danila na Orlovom kršu - Cetinje. Glavni građevinski projekat. Le Pont, Podgorica, 2007.

[13] Lokošek, E.; Kleiner, I. Replacement of stone columns at the ground floor of the Veliki Tabor castle.// Gradevinar. $56,5(2004)$, pp. 267-276.

\section{Authors' addresses}

Svetislav G. Popović, PhD

University of Montenegro,

Faculty of Architecture in Podgorica

Džordža Vašingtona bb,

81000 Podgorica, Montenegro

svetislav@ac.me

Dragutin Đuričić, dipl. ing. civileng.

Le Pont Podgorica

Rimski Trg 21,

81000 Podgorica, Montenegro

lepont@t-com.me

Svetlana K. Perović, PhD

University of Montenegro,

Faculty of Architecture in Podgorica

Džordža Vašingtona bb,

81000 Podgorica, Montenegro

ceca.perovic1@gmail.com 